\title{
Um novo horizonte para a cena - o teatro pós-dramático
}

\author{
Edélcio Mostaço
}

Teatro pós-dramático, de Hans-Thies Lehmann constitui-se em auspiciosa ferramenta para a compreensão do teatro contemporâneo, esmiuçando agudos temas e problemas da teoria e da prática teatral e colocando-os à clara luz das explicações brilhantes.

O autor debruçou-se sobre o período compreendido entre 1970 e 2000, por alguns chamado de novo teatro e por outros de pós-moderno, inventariando a riqueza de seus modos expressivos e as características estruturais que fizeram emergir novos paradigmas na cena ocidental. Como se depreende ao longo da leitura, pós-dramático é termo ambíguo, porém justificado, uma tentativa de síntese entre a situação epocal do fenômeno (o período da pósmodernidade) e suas constituintes estruturais (a pulverização do modelo dramático), simultaneamente sugerindo não apenas os avanços formais dessa produção como, especialmente, seus aspectos de ruptura em relação aos cânones.

O livro já foi objeto de estudos, de modo que vou aqui destacar aspectos menos explorados em outros comentários. ${ }^{1}$ Antes de adentrar as características poéticas dessa produção inovadora, Lehmann dedica os capítulos iniciais a um balanço da noção de drama, tal como consolidada e estudada em nossa cultura. Parte, para tanto, das posições consagradas nos estudos de Peter Szondi (2001), um autor que, como sabido, tomou Hegel como um sólido eixo de referência e Adorno como uma espécie de anjo tutelar, fazendo do pensamento iluminista sua ponta de lança. ${ }^{2}$

A simbiose entre teatro e drama configurou, desde o Renascimento, uma inextrincável rede de permutas e acomodações que fez com que um passasse a ser sinônimo do outro; quando, em realidade, o drama deve ser tomado apenas como uma parcela do teatro, aquela marcada pelo advento do texto dramático forjado a partir das matrizes aristotélicas glosadas pelos diversos tradutores e comentadores renascentistas da Poética. Enfileiram-se nessa corrente desde Robortello e Scalinger até Diderot e Shelley e, na Alemanha, as decisivas intervenções de Lessing, Goethe, Schiller e Hegel, até surgirem as primeiras contestações na pena de Nietzsche e Fuchs. Em meados do século XIX a França engessou definitivamente o gênero através das leis do drama criadas por Brunetière, quando da articulação daquilo que ficou conhecido como dramática rigorosa ou absoluta. Partindo do pressuposto de que o drama é um texto constituído em diálogos que exprimem relações

\footnotetext{
${ }^{1}$ Ver especialmente a revista Humanidades, edição especial, Editora UnB, n. 52, novembro de 2006.

${ }^{2}$ Para uma compreensão desse pano de fundo cultural talvez seja significativo saber que Lehmann foi aluno de Szondi e este, por sua vez, aluno de Emil Steiger, cuja obra Conceitos fundamentais da poética ocupou papel de destaque junto aos estudos consagrados aos gêneros literários nas primeiras décadas do século XX. Os dois últimos seguem, no principal, as proposições de Hegel fixadas em sua Estética, em $O$ sistema das artes bem como em A fenomenologia do espírito. Theodor Adorno escreveu diversas obras sobre a indústria cultural, a música e uma Teoria estética na qual, seguindo a tradição germânica, igualmente se mostra fiel às teses hegelianas, embora as pensando no contexto pós-Marx.
} 
intersubjetivas, cuja forma de espetáculo alcançou com o "palco mágico" dos teatros à italiana seu momento culminante, Szondi inventariou as formas modernas nas quais ele se apresenta (dramaturgia do $e u$, drama estático, drama de conversação, lírico, existencialista e de confinamento), para concluir que a solução brechtiana, efetivada por intermédio de recursos épicos, significou uma superação do formato, alçando o teatro a outro patamar.

Lehmann deslinda com elogiável argumentação tais confusões epistemológicas, artísticas e técnicas, ao enfocar as matrizes forjadas por Hegel:

Quando Hegel entende o belo artístico como uma "reconciliação" dos opostos
em várias camadas, especialmente do belo e do ético, pode-se de fato afirmar
que sob o conceito de "dramático" ele faz valer no âmbito estético aqueles
traços que fazem a pretensão de reconciliação fracassar. O drama não é
simplesmente a manifestação (não problemática) do ético belo, mas sobretudo
a patente crise deste. (p. 67)

Durante séculos o dramático foi associado à dialética, sendo esta percebida como a geração de uma nova realidade a partir do choque entre tese e antítese. Não poucos estudiosos associaram ou descreveram o desenvolvimento social com esse molde cênico - dado seu intrínseco teor de oposição e conflito -, fazendo ver a Revolução como o maior drama da humanidade. Passa despercebido, com essa metáfora, o viés simplesmente narrativo e fictício que esse tipo de discurso alberga, assentado em padrões retóricos inaugurados por Aristóteles e repetido ad nauseam durante muito tempo. Ao postular que quando a história se repete o faz como farsa, Marx estava afirmando, por oposição, o teor sério que ela ostenta em sua primeira instância, tomada como drama. De modo que uma confusa, mas inextrincável associação de sentidos e significados foi acumulando nexos éticos, sociais e, finalmente, políticos entre drama e ação revolucionária, contaminando não apenas sua apreensão como também a da História, quando entendida como sucessão de formas sociais pelo materialismo dialético.

Szondi não deslindou essa equação entre teatro e drama, tomando um pelo outro, de modo que muita gente embarcou na canoa, supondo que a tal epicização do texto dramático constituiu-se num estágio superior da arte cênica. No Brasil, por exemplo, tal perspectiva equívoca surge nas postulações de Iná Camargo Costa e Reinaldo Maia ou nas teses artísticas da Cia. do Latão e do Folias d'Arte, entre outros teóricos e grupos, ao tomarem Brecht como um estágio artístico culminante ou a epicização das narrativas como um patamar expressivo superior para o teatro (o que os leva ao elogio do antigo CPC ou do MST como um plus artístico).

Tais perspectivas há muito foram revistas e desmontadas, quer no terreno da história (a nova história, Bloch, Burke, Le Goff) quer no da filosofia e da política (Arendt, Castoriadis, Althusseur, Foucault, Deleuze/Guattari, Morin, Maffesoli etc.), sem falar na semiótica que, redimensionando o entendimento em torno dos signos e suas articulações entre significante e significado, recolocou a semiose e a representação em outros patamares, possibilitando entender que a linguagem teatral não é nem analógica nem simplesmente simbólica. Ou seja, o ator em cena não é um duplo de si mesmo nem um duplo da classe social que representa na ficção (embora possa, em certos contextos, assumir também tais significados). 
Ainda que Lehmann reconheça o inestimável valor de Brecht no rumo da epicização do teatro contemporâneo - através da introdução de poderosos recursos poéticos de espetáculo, decorrentes do distanciamento - o teatro pós-dramático é um teatro além de Brecht. O que sucedeu foi o abandono de um logos central (o texto ou seu autor), para a explosão das inúmeras vozes caladas que, embora existentes desde sempre no fato teatral (as diversas funções exercidas pela equipe criadora da encenação), encontram agora espaço para sua plena manifestação. E eu complemento, apoiado na perspectiva de Bakhtin, que o novo teatro assumiu em definitivo sua estrutura dialógica e polifônica, evidenciando-se como fenômeno plural que pôde, mais que no romance, efetivamente dar voz às diferentes consciências que o articulam.

\title{
Afirma Lehmann:
}

\begin{abstract}
o polílogo (Kristeva) do novo teatro freqüentemente se liberta de tal ordenamento centrado em um logos. Chega-se a uma disposição de espaços de sentido e ressonância que, sendo aberta a vários usos possíveis, não pode mais ser atribuída sem mais a um só organizador ou órganon (individual ou coletivo). [...] Antes, os atores desenvolvem em uma delimitação previamente dada uma lógica corporal própria: impulsos latentes, dinâmica energética do corpo e do sistema motor. (p. 49)
\end{abstract}

Ou seja, estamos, definitivamente, muito além da mimese.

É a razão pela qual as especulações de Lyotard em torno do teatro energético ganham ênfase nas considerações de Lehmann, ao opor a antiga "representação" à atual dimensão da "intensidade". É preciso mudar de ponto de vista para se assimilar em toda extensão o arco dessas implicações. Bob Wilson, Richard Foreman, Robert Lepage, Pina Bausch, Jan Fabre, Anatoli Vassíliev, William Forsythe, Meredith Monk, Tadashi Suzuki, La Fura dels Baus, entre muitos outros, são alguns dos artistas enfocados e criteriosamente discutidos, a despeito das agudas diferenças que alimentam seus projetos artísticos. Numa produção que escorraçou o texto, poucos autores subsistem - podendo Heiner Mülller, Peter Handke, Botho Strauss, Bernard-Marie Koltès, Valère Novarina e poucos mais reivindicarem guarida nesse universo sem eixo.

Em alentados capítulos prenhes de exemplos e digressões, Lehmann expõe, em mais de 400 páginas, os rumos tomados pela performance, pelo texto, o tratamento dispensado ao tempo e ao espaço, o corpo, as mídias, conformando ampla explanação das possibilidades estéticas propiciadas e experimentadas a partir desse novo teatro. Para o leitor, um instigante convite a rever seus padrões consagrados, desobstruir seus canais de apreensão e abandonar em definitivo os paradigmas erigidos em torno da tradição do drama - ou seja, enfrentar decididamente o teatro do terceiro milênio.

Referências:

SZONDI, Peter. Teoria do drama moderno [1880-1950]. SP. Cosacnaif: 2001. LEHMANN, Hans-Thies. O teatro pós-dramático. SP. Cosacnaif: 2007. 